\title{
Rethinking violence through the narrative of Genesis 4:1-16
}

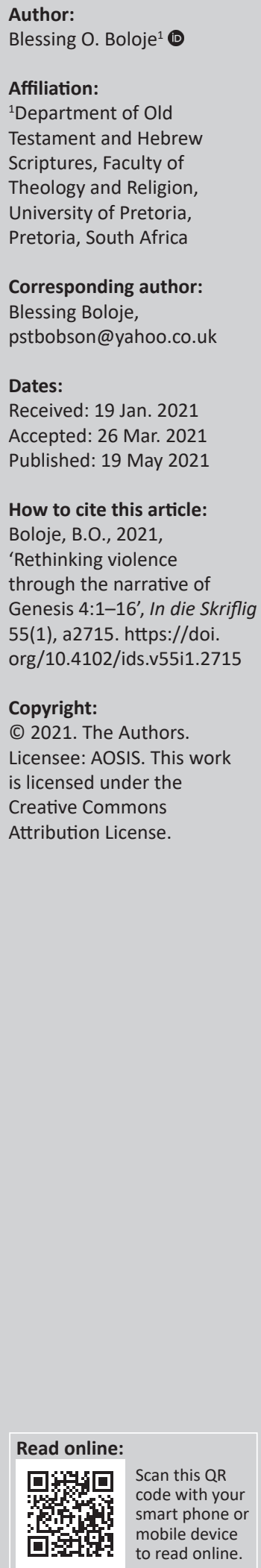

Genesis 4:1-16 is a well-known narrative following the ejection of Adam and Eve from the garden. It is an essential aspect of Genesis' theological unity that consists of a combination of stories that show separation within family and state. The narrative is rich in alternating developmental plot and served as a significant pointer to the divine-human relationship. Obviously, at a time and in settings in which it has become increasingly painful to look at life, as individuals and communities witness the collapse of the pillars of social life, this article identified values and principles, and offered perspectives for dealing with the sequence of violence in order to create possibilities for communal solidarity. In view of the fact that the narrative is rich in its developmental plot, this article exegetically highlighted the textual sub-units in the narrative and theologically attempted to rethink violence from the perspectives of the perpetrator and the victim in God's creation. The theological datum of the article is that violence in the narrative of Genesis 4:1-16 is an offshoot of perceived divine arbitrariness in which the perpetrator is unable to acknowledge divine prerogative. Consequently, the failure of people to manage their dissatisfaction and to control their impulses in the face of incomprehensible divine arbitrariness, hides the inevitability of violent conflict in daily human experiences.

Contribution: The article drew theological and moral implications that will challenge contemporary readers of the Cain-Abel narrative, who are faced with the most profound existential issues of human relationship and thus struggle with violent behaviours of individuals and groups, to embrace its instructive potential for faith and life.

Keywords: Cain-Abel narrative; Genesis 4:1-16; violence; divine arbitrariness; offering; perpetrator and victim.

\section{Introduction}

The Cain-Abel narrative of Genesis 4:1-16 is generally recognised as one of many difficult passages in the Old Testament (Castellino 1960:442). Lohr (2009) notes that:

There appears to be a long-standing interpretive crux in the story of Cain and Abel (Gen 4:1-16) regarding why God looks with favor on Abel but not on Cain. The interpretive instinct to determine the reasons for God's favor is perhaps quite natural: religiously speaking, a deity who favors or disfavors without reason could appear arbitrary or unjust, an issue to resolve (p. 485).

Whatever the origin, Zucker (2020) underscores that:

Genesis 4:1-16 is an abbreviated reflection of a narrative that was known to Israelite society before the setting down of the Torah ... The narrative is characterized by gaps, silences and fateful unexplained actions that provoke more questions than solutions. (p. 8)

The narrative falls within certain dynamic accounts that are full of action, crises, humour, irony, anthropomorphism and emotional tension (see Gn 2:4b-25;3:1-24;4:1-16). These narratives are believed to have been skilfully written by a Yahwist who is conceivably a sophisticated storyteller (Levin 2007:209-230; Römer 2006:9-27). In these narratives, the figures of Adam and Eve have been given more significance than those of their sons due to an individualistic understanding of sin reflected in churches' teaching and practice. Westermann (1974:20) notes that the significant social responsibility of the figures of Cain and Abel in Genesis 4 has, however, always been shrouded in mystery.

Whilst the narrative of Genesis 1-2 portrays an ecstatic paradise filled with intimacy in relationships between the LORD and his creatures, and Genesis 3 describes fragmented intimacy between the LORD and humans, Genesis 4 is interpreted as a narrative of shattered social solidarity between two brothers who sought God's favourable attention (Coats 1993:151-169). Hauser (1980:297-305) underscores the complementary nature of the narratives in Genesis 2-3 and 4, and expounds 
shared thematic links such as primordial characters in their pairs (Adam and Eve, Cain and Abel), divine cautions regarding acts of disobedience to God, divine confrontation, condemnation, severance from God's presence and settlement in the east of Eden. His linguistic analysis identifies a number of parallels such as the use of expressions and ideas like 'know', 'conceive', 'bear', Abel's name and breath of life, 'offering', 'the fruit of the tree', the use of 'his wife' or 'the woman', 'his brother', the 'face' of God and Cain's fallen face. In addition are the motifs of intimacy and alienation which are present within Genesis 2-4. Thus, the theological unity of Genesis consists in a combination of stories that show separation within family and state, along with stories that trace reconciliation within Abraham's family (Mann 1991:351). In view of the significance of the divine-human relationship and the rich alternating developmental plot of the narrative, this article shall exegetically highlight the textual units of the passage (Gn 4:1-16) and attempt to rethink violence ${ }^{1}$ from the perspectives of the perpetrator and victim in God's creation. The article notes that violence (although sinful) in the narrative of Genesis 4:1-16 is an offshoot of perceived divine arbitrariness ${ }^{2}$ in which the perpetrator is unable to acknowledge divine prerogative and live up to his or her own responsibility.

\section{Genesis 4:1-16 and its narrative plot development}

As a well-known narrative, Genesis 4:1-16 follows on the ejection of Adam and Eve from the garden. The passage records the births of Cain and Abel, God's blessing on Adam and Eve (Gn 4:1-2); the religious service (offering) of Cain and Abel (vv. 3-5); God's dialogue with Cain, indicating divine prerogative and Cain's violent response to God's prerogative (vv. 6-8); and God's judgement on Cain (vv. 9-16). The following sub-sections present a textual analysis of the unfolding developments in the plot of the passage.

\section{Sexual union, births and professions (Gn 4:1-2)}

And Adam knew his wife Eve, and she became pregnant and gave birth to Cain And she said, "With [the help of] the LORD I have brought forth a man-child'.

Likewise, she gave birth to his brother Abel. Now Abel kept flocks, and Cain worked the soil.

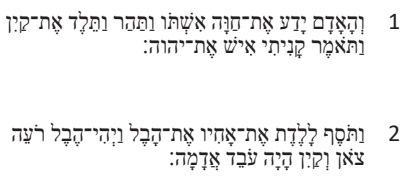

The narrative of Genesis 4 begins with the sexual union of Adam and Eve that resulted in the birth of their firstborn child Cain. The Hebrew verb יָָ [knew] is used as a euphemism for sexual intercourse (Briscoe 1987:71; Reyburn \& Fry 1997:103). Although יָּ in Genesis 4:1 may not be the first sexual intercourse between Adam and Eve (see Gn 2:25), it functions as the primary medium through which man (אדם) could reproduce himself or multiply to fill the

1.This article understands violence as a forceful action with the intention to cause unsolicited damage to someone. It could result to destruction of property, psychological harm and death of its target. It is thus an aggressive, violent action by a perpetrator against a victim (Douglas 2011:809).

2.This article follows Römer's view in which he describes Cain's rejection and Abel's acceptance as emanating from divine arbitrariness giving favourable consideration to some rather than others (see Ex 33:19 - 'I will show mercy to whom I will show mercy'; Römer 2013:112). earth (Gn 1:28). This primary medium produces a second stage of conception, whilst giving birth represents a third stage in the process of man's reproduction. The narrative depicts the birth of Cain, an offspring of the first primal man, as being acquired

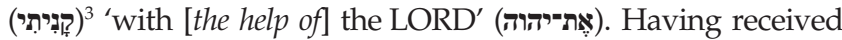
the experience of the curse at birth (Gn 3:16), Eve's exclamation 'with [the help of] the LORD' could simply be because of the pain she went through before eventually giving birth to a man (Ellison \& Payne 1986:119). Although she recognised and acknowledged God as the giver of the child, Cain is presented in the narrative as the possession of his mother, Eve, whom she created or acquired with [the help of] the LORD (Willmington 1981:9). An extension of this creative role is assigned to Cain:

And Cain had sexual relations (YT⿳亠口) with his wife and she conceived, and gave birth to Enoch; and he built a city, and called the name of the city Enoch, after the name of his son (Gen. 4:17). (Callender 2000:201-202)

In verse 2, the narrative introduces the birth of Cain's brother, Abel (דֶֶ), whose name means 'vapour', 'vanity' or 'breath', (appearing seven times in Gn 4:1, 2, 25) (Hamilton 1980:204-205). ${ }^{4}$ The two verbs, וּרֶּ [do again or continue] and לִלֶֶ? [bear] indicate a repeated process through which the first child (Cain) was born. In this way, Abel became the product of a second process of giving birth (Morris 1988:135).

Whilst the birth of Cain was celebrated by Eve, no interjection of joy whatsoever is recorded regarding the birth of Abel (Blenkinsopp 2011:84). All that is indicated in the final section of Genesis 4:2 is the distinction between the two brothers by

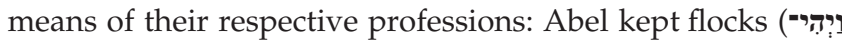

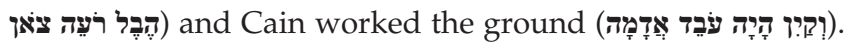
The choice of these different career paths suggests that Adam and Eve may have engaged in both professions which gave them the idea of their choices (see Gn 2:15).

\section{The religious service (offering) of Cain and Abel (Gn 4:3-5)}

As the days go by, Cain brought some of the fruits of the ground as an offering to the LORD.

But Abel brought fat portions from some of the firstborn of his flock. And the LORD looked with favour on Abel and his offering,

But on Cain and his offering he did not look with favour. So Cain became very angry, and his face was downcast.

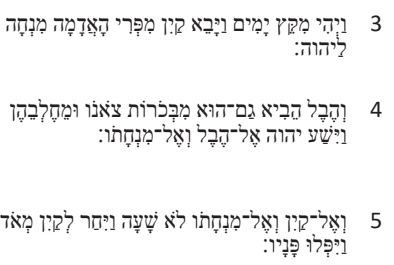

In Genesis 4:3-5, the narrative placed Cain and Abel in

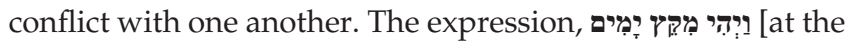
end of days (or a period)], is used for beginning a new phase or page of narrating an event. Following the normal rule of family authority and primacy of the firstborn, the narrative presents Cain as bringing an offering to the LORD (Gn 4:3).

3.There is an obvious play on words (paronomasia) with respect to the meaning of the name קיון The means 'acquired' of 'possession', while the nacquired' or (Gn 14:19, 22; Pr 8:22); 'purchase' or 'acquire' (Ex 15:16; Dt 32:6; Ps 78:54); or 'produce' (Ps 139:13).

4.It is suggested that the name could be a product of the curse of God on the woman during child bearing. It could simply be a prophecy concerning the short life he would live, or a name given to someone who will die at a young age (see Skinner 1995:101). 
The offering (מָנָָּה which can mean gift) (Lohr 2009:486) of

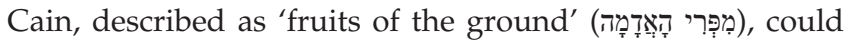
just be a means of recognising God as the owner of all and giver of power to create wealth or simply an acknowledgement of Yahweh's lordship over their lives as the creator (see Gn 1:1; Dt 8:18; Morris 1988:136).

The narrative in Genesis 4:4 employs two words to

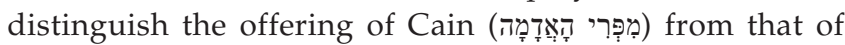

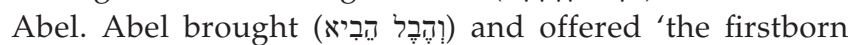

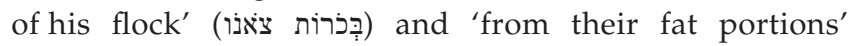

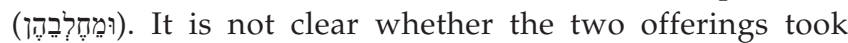
place simultaneously or sequentially: Abel's offering immediately after Cain's offering. The Hebrew verb שָָָׁ [to gaze at intently, pay attention, regard] is used by the narrator (Gn 4:4-5) to cast Abel and his offering very positively, and Cain and his offering more negatively. The narrative shows that the LORD looked with favour on Abel and his offering, but did not consider either the person of Cain or his offering. Whilst the narrator does not give reasons for the acceptance and/or rejection of their religious devotion, a number of Jewish and Christian liturgical texts have commented on the divine preference of Abel over Cain. ${ }^{6}$

The narrator seems to have used the story to draw attention to polemical hints in favour of a nomadic culture rather than a sedentary one (Antwi 2017:13; Nichol 1978:220; Speiser 1964:31; Waltke 2001:97). Abel is viewed as presenting the best of his animals for his religious service, whilst Cain offered a token of his farm produce to fulfil an obligation (Waltke 1986:369). Abel's offering was offered in faith and followed the prescribed ritual of sacrifices in Mosaic Law of peace offering ( $\operatorname{Lv} 17: 11,3: 16)$, the prescribed of 'firstly' sacrifice of blood (slaughtering of animal). God's disposition regarding the offerings of both brothers could have been known to them through some particular method of God's acceptance of an offering or a sacrifice (Lv 9:24, Jdg 6:21; 1 Ki 18:28; 1 Chr 21:26; 2 Chr 7:11) - how fire would descend from heaven to consume the accepted offering and the other one was untouched by the heavenly fire (Kyle 1990:9; Lewis 1994:494). However, Von Rad (1972:104-105) speculates that, within the context of the entire ancient orient, the acceptance or rejection of sacrifice is reflected in the disposition of the victim. Consequently, one can imagine some of such approach here. Such conjecture may, however, not be very convincing.

Within the narrative, one can observe a clear chiastic and stylistic variation in the arrangement of the order of the brothers: the movement from Cain to Abel and Abel to Cain.

5.Outside the narrative of Genesis $4: 3-5,3$, 3 an appears in Genesis as gifts such as those offered to Esau by Jacob $(32: 14,19,21-22 ; 33: 10)$, as well as those taken to Egypt by Jacob's sons (43:11, 15, 25-26). According to Lewis (1994:481-482), 'The term, which without distinction describes both Cain's and Abel's offering, may mean "tribute" (1 Ki 4:21 [5:1]; 10:25). It usually is used of cereal offerings ... when in worship settings, but it also may refer to an animal offering (cf. 1 Sm 2:17; 26:19; Ml 1:10, 13; 2:13).'

6.For speculations regarding the rejection of Cain's offering, see Bredin (2003:80) Collins (2006:200, 212), Levenson (1993:72) and Waltke (1986:368-369). Bredin (2003:80), for example, quoting the Targum of Pseudo-Jonathan 4:8-11, indicates that the narrative of Abel over Cain is expanded with striking additions.
Although it is expected that the order of the brothers is followed in the process of presenting their offering, there is a reversal in the response of God. The normal rule of family authority and primacy of the firstborn and the younger child is in disarray. In both content and style, the narrative indicates that God regards Abel first and Cain last. This reversal motif - the preference of the younger son to the firstborn - is frequently and consistently found elsewhere in the Bible and, especially, in Genesis. Although David's ascent over his brothers is seen as a later development of the same motif, God's preference of the offering of Abel over Cain's is obviously the first in the series, whilst the response of Cain is the most ruthless (Hendel 2020). ${ }^{7}$

The immediate reaction of Cain to the rejection of his offering was his expression of excessive anger and utter disappointment and depression. The Hebrew verb חָרָה is translated as 'burn with anger' (Kyle 1990:9). Cain became angry, furious and bitter, because God did not just reject his offering, but there was another person that was accepted, namely his younger brother, Abel. Cain was not only obsessively angry, but his face became very heavy and unbearable. The Hebrew expression for his utter depression

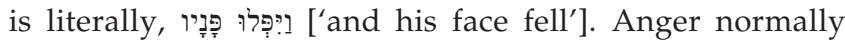
affects the expression of the face. The face of Cain reveals the burning inherent in anger. His face was an expression of his anger. God, however, had already looked at Cain's heart and saw his deep-rooted wickedness. Cain's anger revealed the disposition of his heart and of his personality. He was not pleased with the outcome of their devotion to God.

\section{God's dialogue with Cain and Cain's response in violence to God's prerogative (Gn 4:6-8)}

And the LORD said to Cain, 'Why are you angry? Why is your face downcast?

If you have done what is right, would you not have been accepted? But if you do not do what is right, sin is crouching at your door; it desires to have you, but you must

And Cain said to his brother Abel: And it happened that while they were in the field,

Cain attacked his brother

Abel and killed him.

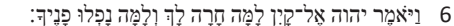

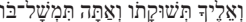

8

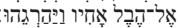

7

Genesis 4:6 opens with God's dialogue with Cain. There are two aspects in this initial dialogue. In the opening part, God gave a lovely counsel on how Cain could rectify the past and in the closing part, God gave warnings on the evil that may likely take place if he allows it. God, in his sovereignty, responded to the attitude which was expressed by Cain with two interrogatives similar to that of Adam and Eve in the garden (Gn 3:9). The two questions, 'Why

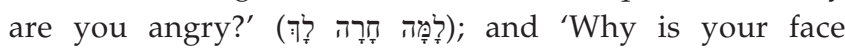

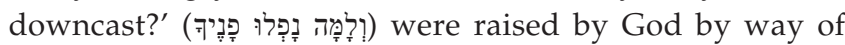

7.Such obvious instances in Genesis includes Isaac over Ishmael (Gn 16; 21:1-21) Jacob over Esau (Gn 25:20-34; 27:1-45), Rachel over Leah (Gn 29:16-35), Joseph Jacob over Esau (Gn 25:20-34; 27:1-45), Rachel over Leah (Gn 29:16-35), Joseph
over his brothers (Gn 37:1-11; 37-50) and Ephraim over Manasseh (Gn 48:7-19) (Antwi 2017:12; see also Gordon \& Rendsburg 1997:129-130). 
trying to assist Cain when God identified the tension that Cain's grief was causing him and the tragedy that it could produce. God already knew what the answers to the questions are. The LORD's questions imagine a divine prerogative that was not bias and oppressive; God was fair and just over Cain and Abel and their offerings. Abel and his offering were accepted on merit. The declarative conditional particle 'if' in the expression, 'If you do what is right' (הלוֹא אם התיתיטיב), which could also be written as, 'If you had done well', or 'If you will do well', highlights the reason why Cain and his offering was not accepted. On the contrary, Cain still has the prospect of making amendment if he would learn to comfort himself, work harder to make things right and be accepted again (Nichol 1978:232). His choice to do well will relieve him of his miserable and depressed countenance and he would be lifted up in joy. The Hebrew verb, רבֵֵ, conveys the idea of crouching with the goal of attachment (see Gn 49:9), lying down (49:14), or lying under a weight (Ex 23:5). Thus, the expression [סטָטת רביץ [sin crouching at the door], indicates the proximity of sin to Cain and how forceful it is to rule over him. God advised Cain to do everything to overcome the sin that is already in his heart and its manifestation; if he does not overcome it, it would lead to more tragic and dubious consequences.

Within the interval of silence between God and Cain, the narrative unfolds in a moment of conversation between Cain and his brother, which culminated in the murder of Abel. Several ancient versions (such as the Septuagint [LXX], Vulgate [Vg.], Syriac, Samaritan Pentateuch) provide the textual gap in the Masoretic Text's rendering of Genesis 4:8, 'And Cain said to his brother Abel ...' Modern versions such as New Jerusalem Bible (NJB), New International Version (NIV), and New Revised Standard Version (NRSV), insert 'Let us go out to the field' to verse 8 and the New American Standard Bible (NASB), New King James Version (NKJV), King James Version (KJV), English Standard Version (ESV), read 'they went to the field'. The narrative of verse 8 could be interpreted as deliberate literary technique that is aimed to create tension, because what Cain said to his brother is not indicated. ${ }^{8}$ What is clear in the narrative is the fact that Cain could not achieve peaceful conversation with Abel. He probably pretended that all is over and decided to live with Abel in a friendly manner until his inner anger was avenged. Consequently, under a brotherly familiarity, Cain concealed his premeditated and calculated intention until a convenient time and place. Whilst being away from home and alone

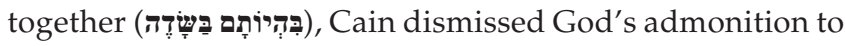
rule over the crouching sin, and proceeded to finally allow sin to prevail. The חטָָָת [sin] that began in the heart with jealousy move to anger, hatred and then to violence of the first murder with the hand.

8.It is speculated that Cain spoke against Abel or conspired against him. For speculations and expanded discussion of Genesis 4:6-8 in the Targums see Bassler speculations and expanded discussion of Genesis 4:6-8 in the Targums see Bassler
(1986:56-64) and Byron (2011:66-69). Also see Jacobson (2005:564-565) and Reis $(1986: 56-64)$ and
$(2002: 107-113)$.

\section{God's verdict on Cain (Gn 4:9-12)}

And the LORD said to Cain

'Where is your brother Abel?' And

he replied, 'I don't know'. 'Am I my

brother's keeper?'

And he said, 'What have you done?

Your brother's blood cries out to me

from the ground.

And now you are under a curse from the ground, which opened its mouth

to receive your brother's blood from your

hand.

When you cultivate the ground, it will no longer yield its strength to you. You shall be a fugitive and wanderer on the earth'

And Cain said to the LORD, 'My

punishment is greater than I can bear'.

Behold, you have banished me this

day from the face of the earth; and from

your presence I shall be hidden; and I shall

be a fugitive and a vagabond in the earth.

and it will come to pass, such that every

one that finds me will kill me.

And the LORD said to him, 'Therefore

whoever kills Cain, vengeance shall

be taken on him sevenfold'. And the

LORD set a mark upon Cain, lest

anyone finding him should kill him.

And Cain went out from the presence of

the LORD, and dwelt in the land of Nod,

east of Eden.

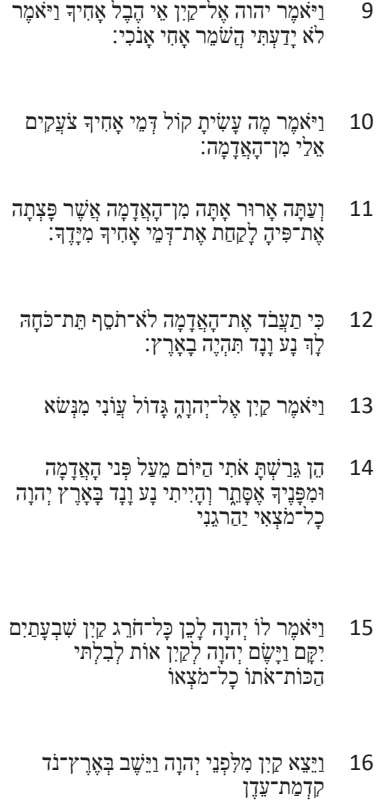

The narrative of Genesis 4 develops dramatically to the point of God's verdict on Cain. The question, הֶרֶל אָחדיף ['Where is your brother Abel?'] is similar to the inquiry the LORD made of Adam in the garden, 'Where are you?' (Gn 3:9). In both situations, the question highlights inherent disobedience. The obvious reversal of roles in the narrative may have added up to Cain's response to the LORD's question immediately after the murder of Abel. The response of Cain, 'I don't know ... Am I my brother's keeper?' opens several dramatic paradoxes. Firstly, Cain certainly knew where Abel was, because he murdered him. Secondly, he must have inherited the inclination of attempting to excuse oneself of blame from his parents. Thirdly and more importantly, as his brother's keeper (שֵָׁ), literally means one who 'guards' 'protects' 'keep'), he must have had some sense of responsibility for keeping his brother. His response, however, indicates a denial of the brotherhood relationship with Abel whom he was supposed to keep שֵָׁ and protect from harm.

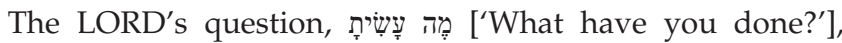
which is similar to the question God asked Eve (Gn 3:13), is intended to prompt Cain to confess with his mouth what he

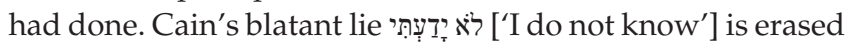
by the motif of the voice that reaches its climax in the

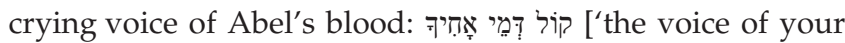

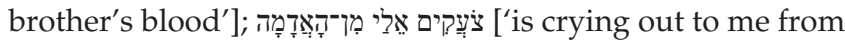
the ground'] (Gn 4:10). The literary motif of the voice of Abel's blood, shed in violence and crying out to God, is developed in several Jewish and Christian texts (see Byron 2011:177-190; Hilhorst 2003:119-127; Kugel 1990:180). God's sympathetic identification in the narrative is not only simply about Abel's life, but more importantly the entrance of violence into a society with profound and imaginable potential of destroying the land and the people, 
because blood vengeance would invariably result in a cycle of violence (Noort 2003:98-99). The inevitable logic of this motif of voice unfolds in God's fatherly pity on Abel and thus curses Cain, 'And now you are under a curse from the ground, which opened its mouth to receive your brother's blood from your hand' (Gn 4:11). The narrative underscores

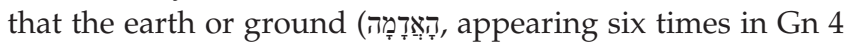
alone: vv. 2, 3, 10, 11, 12, 14) as an entity acknowledged the agony and disgust of the blood of Abel that has been shed irresponsibly and responded to the violence by

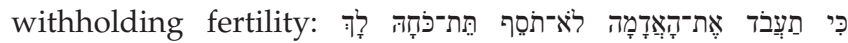
['When you cultivate the ground, it will no longer yield its strength to you'] (Gn 4:12a). Commenting on this development, Westermann (1984:306) notes that the ground, 'gulps the blood of the victim down its throat. It reacts to the blood by denying arable soil its "power," i.e., the power of fertility and so its produce.' The ground that had once been cursed because of Adam's disobedience is now cursing Cain.

In Adam's case, he was permitted to continue his occupation of farming the ground regardless of the difficulties he would experience (Gn 3:18-19). Cain, however, was driven from his occupation of cultivating the ground. The ground will be unproductive, as it will 'no longer yield its strength' to him. The implication here is that he will not be able to farm (West 1990:35). The hostility of the ground to Cain would be to such great an extent that he cannot derive sustenance from cultivating it and, consequently, was forced to wander:

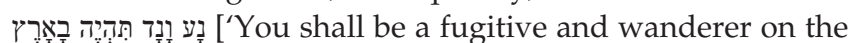

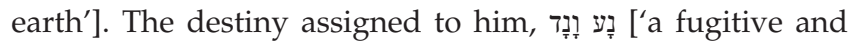
wanderer'] suggests that his banishment is absolutely as ruthless as if he had been killed (Westermann 1984:310). He was driven from people, became a fugitive and a wanderer having no home and a settlement. His realisation of the severity of the curse can explain his objection (Gen. 4:13).

Cain exclaimed, 'My punishment is greater than I can bear'

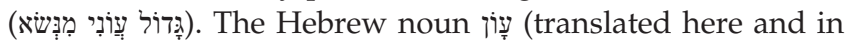
several other translations as 'punishment') carries other possibilities such as offence, guilt, misdeed or sin. The Hebrew verb נְִָָ [to lift, carry] can be translated as 'pardon' or 'forgive' (see LXX; Vg.; Gn 18:26; 40:13; 2 Ki 25:27). His complaint in Genesis 4:13-14 indicates a three-fold perspective of his punishment: He was banished from his

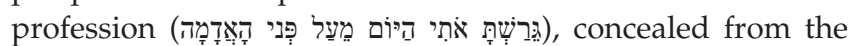

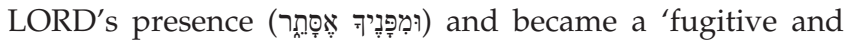

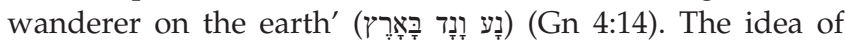

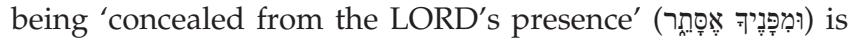
only inferred by Cain, because it was not part of the LORD's pronouncement. It imagines Cain's realisation and acknowledgement of his broken relationship with God that has further implications on him.

The narrative does not indicate Cain's sense of remorse. However, in Cain's protestation of his punishment, one can observe that Cain understands the weight of his actions and believes that he will be vulnerable. In view of his recognition of the natural community response, Cain discovers that he was vulnerable and thus laments his lack of security and protection. The shift in the narrative is, however, found in God's corrective and redemptive response to Cain (Gn 4:15). Rather than aligning with the instinctive logical community response to a perpetrator of violence, the narrative shows God's identification with Cain who lacks protection and whose life is in danger by enforcing

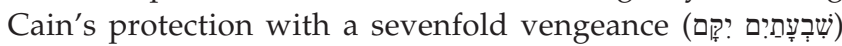
and by placing a mark of protection on him (Van Wolde 1991:39). This mark or sign (אוֹ) which is similar to other signs in the narratives of Genesis $(1: 14 ; 9: 13)$, is considered as both a mark of guilt (reflecting his inner state; the mark pictures him outwardly as a murderer) and grace (as one who is under God's protection) (Brueggemann 1982:60). The narrative thus places vengeance within the sweep control and ultimate prerogative of God. The narrative concludes with Cain observing part of the punishment for his violence (as he inferred) by leaving the LORD's presence

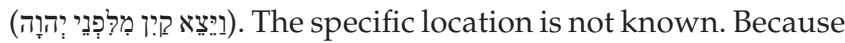
the term Nod (נוֹד) is formed from the same root as [wanderer] (see Gn 4:12,14), it is probable that the term indicates Cain's perpetual and eternal wandering.

\section{Rethinking violence: Cain, Abel and God in the perspective of Genesis 4:1-16}

From the foregoing textual analysis of Genesis 4:1-16, this article attempts to rethink violence from the perspectives of the perpetrator and the victim in God's creation. Genesis 4:1-16 is essentially about the violence of Cain and his outrageous attack on his innocent brother, Abel. Consequently, readers of Genesis are mostly expected to identify with Abel and his God. In this narrative, Abel is presented as the primeval representation of innocence, and Cain is understood as the embodiment and personification of evil.

Instructively, God, who distributes the favours of his providence, empowered Cain to do well. Accordingly, Cain was to maintain a sense of responsibility to God, his brother and the world. The failure of Cain to live up to the height of his responsibility is the primary concern and issue at stake in Genesis 4 (Lacocque 2010:18). The narrative conveys several perspectives on the understanding of violence in the realm of theological anthropology and community living.

One of the messages of the narrative is that individuals or groups who do not have confidence in God's prerogative and justice have the potential to perpetrate violence (Noort 2003:105). The Cain-Abel narrative presents an image of God whose prerogative and acceptance appear to be inexplicable and arbitrary. This inexplicable and arbitrary picture of divine prerogative lies in the background of Cain's violence. The experience of rejection, which Cain witnessed, robs him of his integrity and viable self-esteem, 
and consequently, his inner struggle could not allow him to take responsibility for the management of his emotions. This failure of emotional management allows the narrator or narrative to place the consequent outcome of the story on the shoulders of Cain. The narrative develops a cycle of violence in which the phase of failing to manage his emotions (see Gn 4:5-7), arising from the experience of rejection or failure and insecurity, results in a breakdown of communication (see Gn 4:8) and denial of brotherly, social responsibility (Gn 4:9; Swenson 2006:380). This layer of responsibility in the cycle of violence is crucial in understanding the complicity of violence in many situations in the daily human experience. The narrative does not present an evaluation of the character of Cain, but rather, it concentrates on his attitude and the impact it had on his relationship with his brother, community and God. As a perpetrator of violence against his brother, Cain severed his bonds of brotherhood, of relationship and responsibility and became an infectious character whose presence the community places the community at the risk of continued violence (Girard 1988:86), and eventually alienated himself from the presence of God.

In the drama of the narrative, the victims of violence include Abel and, indirectly, also the ground. Abel, the silent, innocent and direct victim of violence is presented as the only divinely favoured figure in the post-Eden drama. Abel is depicted as innocent and helpless. However, at death, his spilled blood assumed a voice that spoke from the ground to God against his murderer (Gn 4:10). This literary motif of Abel's blood, seeking vengeance $^{9}$ from the ground or earth (מןו-דָאָדָדָהָה), gives prominence to the spilled blood of Abel:

... in which is life, belonged to the group, to the family (בית אב), to the clan (משפחה), and had to be returned in the event of a member of the family or clan being killed. (Noort 2003:98)

It is the responsibility of the community to prevent violence and bloodshed, and once it occurs, vengeance must be sought. Blood vengeance, which includes the basic idea of the ius talionis, serves the purpose of restricting unlimited '(blood) vengeance' and functions:

... as the only possible form of doing justice in a world where the legal system has not developed far enough to enable state or society to take over the role of the judge. (Noort 2003:99)

Noort (2003:99) observes that blood vengeance plays an important role in the narrative parts of the Hebrew Bible (2 Sm 2:12ff, 3:20ff; 1 Ki 2:28ff). Although these texts demonstrate a never-ending story of blood vengeance, it is clear, however, that the biblical narrators were conscious of the fact that blood vengeance could not guarantee justice, but only reoccurring retaliation and a never-ending drama (see $2 \mathrm{Sm} \mathrm{13;} \mathrm{14:6ff).}$

In order to remove the responsibility of vengeance from the community, the narrative clearly indicates the outcome of 9.Several New Testament passages allude to the cry of Abel's blood in search of vengeance (see Mt 23:35; Lk 11:51; Heb 12:24) the spilled blood of Abel. In the narrative, the LORD is cast in the role of the avenger of blood. Although the verdict was announced by the LORD, the ius talionis was

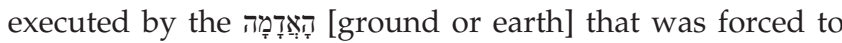
drink the spilled blood of the victim of violence; the curse severed the connection between Cain and the earth. As a way of dealing with the 'spiralling violence' (Wright 2004:216) in the community, the narrative presents God as not only identifying with the victim of violence, but also as a protector of the vulnerable. Although the narrative depiction of God's mitigation and redemption extended to Cain may be seen to be problematic, ${ }^{10}$ in view of the different understandings and theories of justice, ${ }^{11}$ the punishment of expulsion, נִָנָ ['a fugitive and a wanderer'], serves as a viable substitute in the case of contradicting brotherly devotions (Noort 2003:101). In line with the understanding of retributive justice that must balance the scales of punishment with the goal of reforming the offender, the healing of the victim and the repair of relationships (Marshall 2001:97-140), Cain's punishment must be seen as a divinely provided redemptive opportunity for learning about the implications of his actions, of developing new ways of dealing with emotions and, consequently, creating personal redemptive possibilities and community healing. This perspective helps one to understand that even in situations of fragmented relationship emanating from violence, the possibility of redemption and healing does exist. The narrative presents God as closely and actively present in the unfolding drama of Cain and Abel not only as protector of the vulnerable, but also as a guarantor of vengeance and justice amid violence irrespective of the intricacies and challenges that violence creates and the human responses it generates.

\section{Conclusion}

Genesis 4:1-16 is a post-Edenic narrative about brothers securing their livelihood outside Eden. As farmers and keepers of livestock, they are inevitably not in any physical opposition. They are, however, two model groups that obviously have contrary concerns. On the one hand, the narrative involves the birth of the two brothers, Cain and Abel, and their religious devotion to the LORD (Gn 4:1-8). Abel and his offering of blood are received favourably, whilst Cain and his vegetarian offerings are unaccepted. Cain's recollection of his rejection, his inability to comprehend God's prerogative and justice, his struggle to manage his emotions and understand his responsibility forced him into the act of violence that resulted in the murder of his brother, Abel, whose life passed away like vapour (הֶָ). On the other hand, Cain the murderer is cursed by the ground or earth, given protection by God, and destined to be a wandering vagabond (Gn 4:9-16).

The narrative provides a stimulating context for contemplating on and responding to violence in daily human experiences.

10. Byron (2014.24) argues that, while there are many people in the Bible whose deaths are not mentioned the silence over Cain's death might suggest that he lived deaths are not mentioned, the silence over Cain's death might suggest that he lived a long life and died naturally. Not only does Cain escape capital punishment, but he is even able to marry, raise children and build a city. Unlike Abel, Cain's story has a
happier ending, which seems wholly unjust.'

11.For a theory of justice that requires capital punishment for cases of murder, see Kass (1996:44) who argues that capital punishment seems to be the ideal form of justice for the victim without which society will destroy itself. 
The Cain-Abel narrative is a noteworthy reminder that violence against humanity is a distinctive characteristic of societal breakdown in the actual world in which inexplicable success or misfortune between religiously, socially, politically and economically determined individuals or groups play a role in everyday life. The narrative does not only show that violence exists in this material world from the very foundation between varying individuals and groups, but also offers perspectives for dealing with the sequence of violence in view of creating possibilities for communal solidarity, peace and growth. Cain's killing of Abel in the Genesis narrative obviously becomes a constant reminder of the fragility of the bond of brotherly social solidarity and the deficiency of a world where there is no violence (Bremmer 2003:91). Although violence is inevitable in daily human experience, the CainAbel narrative shows that human response to violence must open redemptive opportunities for learning, behavioural change, forgiveness, reconciliation and the possibility of both personal and community healing.

\section{Acknowledgements Competing interests}

The author declares that he has no financial or personal relationships that may have inappropriately influenced him in writing this article.

\section{Author's contributions}

B.O.B. declares that he is the sole author of this research article.

\section{Ethical considerations}

This article followed all ethical standards for research without direct contact with human or animal subjects.

\section{Funding information}

This research received no specific grant from any funding agency in the public, commercial or not-for-profit sectors.

\section{Data availability}

The author confirms that the data supporting the findings of this study are available within the article.

\section{Disclaimer}

The views and opinions expressed in this article are those of the author and do not necessarily reflect the official policy or position of any affiliated agency of the author.

\section{References}

Antwi, E.K.E., 2017, 'Younger brother motif in Genesis as an object of love and hatred in the family: Tensions, conflicts and reflections for the contemporary African family', Old Testament Essays 30(1), 11-29. https://doi.org/10.17159/23123621/2017/v30n1a3

Bassler, J.M., 1986, 'Cain and Abel in the Palestinian Targums: A brief note on an old controversy', Journal for the Study of Judaism in the Persian, Hellenistic, and Roman Periods 17(1), 56-64. https://doi.org/10.1163/157006386X00059
Blenkinsopp, J., 2011, Creation, un-creation, re-creation: A discursive commentary on Genesis 1-11, T\&T Clark, London.

Bredin, M., 2003, Jesus, revolutionary of peace: A nonviolent Christology in the book of revelation, Paternoster, Milton Keynes.

Bremmer, J.N., 2003, 'Brothers and fratricide in the Ancient Mediterranean: Israel, Greece and Rome', in G.P. Luttikhuizen (ed.), Eve's children: The biblical stories retold and interpreted in Jewish and Christian traditions, Themes in Biblical Narrative 5, pp. 77-92, Brill, Leiden.

Briscoe, S.D., 1987, Genesis. Word Books Publisher, Waco TX. (The communicator's commentary series).

Brueggemann, W., 1982, Genesis, John Knox, Atlanta, GA.

Byron, J., 2011, Cain and Abel in text and tradition: Jewish and Christian interpretations of the first sibling rivalry, Brill, Leiden. (Themes in Biblical Narrative, 14).

Byron, J., 2014, 'Biblical views: Did Cain get away with murder?', Biblical Archaeology Review 40(3), 24-25.

Callender, D.E. Jr., 2000, Adam in myth and history: Ancient Israelite perspectives on the primal human, Eisenbrauns, Winona Lake, IN. (Harvard Semitic Studies, 48).

Castellino, G.R., 1960, 'Genesis IV 7', Vetus Testamentum 10(1), 442-445. https://doi. org/10.1163/156853360X00445

Coats, G.W., 1993, 'Strife and broken intimacy: Genesis 1-3 prolegomena to a biblical theology', in G.W. Coats (ed.), The Moses tradition, pp. 151-169, JSOT Press, Sheffield Academic Press (The Library of Hebrew Bible/Old Testament Studies 161).

Collins, C.J., 2006, Genesis 1-4: A linguistic, literary, and theological commentary, P\&R Publishers, Phillipsburg, NJ.

Douglas, M., 2011, 'Violence', in J.B. Green (ed.), Dictionary of scripture and ethics, pp. 809-810, Baker, Grand Rapids, MI.

Ellison, H.L. \& Payne, D.F., 1986, Genesis 1-11, Zondervan Publishing House, Grand Rapids, MI. (The International Bible Commentary).

Girard, R., 1988, Violence and the sacred, Continuum, London.

Gordon, C.H. \& Rendsburg, G.A., 1997, The Bible and the Ancient Near East, Norton \& Company, New York, NY.

Hamilton, V.P., 1980, 'דברֶ, in R.L. Harris (ed.), Theological wordbook of the Old Testament, pp. 204-205, Moody Press, Chicago, IL.

Hauser, A.J., 1980, 'Linguistic and thematic links between Gen 4:1-16 and Gen 2-3', Journal of Evangelical Theological Society 23(4), 297-305.

Hendel, R., 2020, 'The first murder (Gen 4:1-16)', Bible Odyssey, viewed 30 December 2020, from https://www.bibleodyssey.org/en/passages/mainarticles/first-murder

Hilhorst, T., 2003, 'Abel's speaking in Hebrews 11.4 and 12.24', in G.P. Luttikhuizen (ed.), Eve's children: The biblical stories retold and interpreted in Jewish and Christian traditions, pp. 119-127, Brill, Leiden. (Themes in Biblical Narrative, 5).

Jacobson, H., 2005, 'Genesis IV 8', Vetus Testamentum 55(4), 564-565. https://doi. org/10.1163/156853305774651941

Kass, L.R., 1996, 'A genealogy of justice', Commentary 102(1), 44-51.

Kugel, J.L., 1990, 'Cain and Abel in fact and fable: Genesis $4-16$ ', in R. Brooks \& J.J. Collins (eds.), Hebrew Bible or Old Testament 2, pp. 167-190, University of Notre Dame, Notre Dame, IN.

Kyle, Y.M., 1990, Genesis: The Wycliffe Bible commentary, Moody Press, Chicago, IL.

Lacocque, A., 2010, Onslaught against innocence: Cain, Abel, and the Yahwist, James Clarke \& Co., Cambridge.

Levenson, J.D., 1993, The death and resurrection of the beloved son: The transformation of child sacrifice in Judaism and Christianity, Yale University Press, New Haven, CT.

Levin, C., 2007, 'The Yahwist: The earliest editor in the Pentateuch', Journal of Biblical Literature 126(2), 209-230. https://doi.org/10.2307/27638432

Lewis, J.P., 1994, 'The offering of Abel (Gen 4:4): A history of interpretation', Journal of Evangelical Theological Society 37(4), 481-496.

Lohr, J.N., 2009, 'Righteous Abel, wicked Cain: Genesis 4:1-16 in the Masoretic text, the Septuagint, and the New Testament', The Catholic Biblical Quarterly 71(3), 485-496.

Mann, TW. 1991, 'All the families of the earth: The theological unity of Genesis', Interpretation 45(4), 341-353. https://doi.org/10.1177/002096430004500402

Marshall, C.D., 2001, Beyond retribution: A New Testament vision for justice, crime and punishment, Eerdmans, Grand Rapids, MI.

Morris, H.M., 1988, The Genesis record: A scientific and devotional commentary on the book of beginnings, Baker Book House, Grand Rapids, MI.

Nichol, D.F., 1978, The Seventh-day Adventist Bible commentary: The holy Bible with exegetical and expository commentary, Review and Herald Publishing Association, Washington, DC.

Noort, E., 2003, 'Genesis 4:1-16. From paradise to reality: The myth of brotherhood', in G.P. Luttikhuizen (ed.), Eve's children: The biblical stories retold and interpreted in Jewish and Christian traditions, Themes in Biblical Narrative 5, pp. 93-104, Brill, Leiden.

Reis, P.T., 2002, 'What Cain said: A note on Genesis 4.8', Journal for the Study of the Old Testament 27(1), 107-113. https://doi.org/10.1177/030908920202700106

Reyburn, D.W. \& Fry, M.E., 1997, A handbook on Genesis, New York, NY. (United Bible Societies). 
Römer, T.C., 2006, 'The elusive Yahwist: A short history of research', in T.B. Dozeman \& K. Schmid (eds.), A farewell to the Yahwist? The composition of the Pentateuch in recent European interpretation, SBLSS 34, pp. 9-27, SBL Press, Atlanta.

Römer, T.C., 2013, Dark God, Paulist Press, New York, NY.

Skinner, J., 1995, A critical and exegetical commentary on Genesis, Scribner, New York, NY.

Speiser, E.A., 1964, Genesis: Introduction, translation, and notes, Doubleday \& Company, Inc., New York, NY. (Anchor Bible, 1)

Swenson, K.M., 2006, 'Care and keeping east of Eden: Gen 4:1-16 in Light of Gen 2-3', Interpretation 60(4), 373-384. https://doi.org/10.1177/ 002096430606000402

Van Wolde, E., 1991, 'The story of Cain and Abel: A narrative study', Journal of the Study of the Old Testament 16(52), 25-41. https://doi.org/10.1177/ 030908929101605202

Von Rad, G., 1972, Genesis: A commentary, SCM, London. (Old Testament Literature).
Waltke, B.K., 1986, 'Cain and his offering', Westminster Theological Journal 48(2), 363-372.

Waltke, B.K., 2001, Genesis: A commentary, Zondervan, Grand Rapids, MI.

West, G.O., 1990, 'Two modes of reading the Bible in the South African context of liberation', Journal of Theology for Southern Africa 73, 34-47.

Westermann, C., 1974, Creation, Fortress Press, Philadelphia, PA.

Westermann, C., 1984, Genesis 1-11: A commentary, Fortress Press, Minneapolis, $\mathrm{MN}$. (Continental Commentaries).

Willmington, H.L., 1981, Willington's guide to the Bible, Tyndale House Publishers Inc., Carol Stream, IL.

Wright, C.H., 2004, Old Testament ethics for the people of God, InterVarsity Press, Leicester.

Zucker, D.J., 2020, 'My punishment is too great to bear: Raising Cain', Biblical Theology Bulletin 50(1), 7-21. https://doi.org/10.1177/0146107919892839 